\title{
PENINGKATAN SEL OSTEOBLAST MANDIBULA TIKUS WISTAR JANTAN YANG DIBERI FERMENTASI TEH KOMBUCHA
}

\author{
Ni Wayan Arni Sardi ${ }^{1}$ I Dewa Made Sukrama ${ }^{2}$, Bagus Komang Satriyasa ${ }^{3}$ \\ ${ }^{1}$ Bagian Periodonsia, Fakultas Kedokteran Gigi Universitas Mahasaraswati Denpasar \\ ${ }^{2}$ Bagian Mikrobiologi, Fakultas Kedokteran, Universitas Udayana \\ ${ }^{3}$ Bagian Farmakologi, Fakultas Kedokteran, Universitas Udayana \\ email: arnidentist@unmas.ac.id
}

\begin{abstract}
Osteoblasts are bone-forming cells to grow and play a role in regulation of bone metabolism, including alveolar bone. Imbalance of osteoblasts number in bone formation may lead loss of bone mass, which is causes osteoporosis. Reactive Oxygen Species (ROS) is an oxidant that take important roles in osteoclast activation, osteoclastogenesis and activation of osteoblasts inhibition. Kombucha tea has antioxidant effects. This study was conducted to determine Kombucha tea fermented on 14 days make the osteoblasts in the mandibular bone of male wistar rat more numerous. This research was a purely experimental method with Randomized Post Test Control Group Design. Subjects consisted of ten of three - month male wistar rats were divided into 2 groups. Control group received aquadest for 30 days, on the other hand the treatment group were treated by $8 \mathrm{ml}$ of Kombucha tea for 30 days. On the $31^{\text {st }}$ day, rats were euthanized for tissue sampling and histological preparation of mandibular bone and subjected for HE staining. The test results based on comparison between the control group and treatment group with independent t-test showed that there were significant differences in osteoblasts number in mandibular bone of wistar rats $(\mathrm{p}<0.05)$. Kombucha tea contain epicatechin gallate (ECG) that stimulate osteoblasts differentiation and inhibit induction of Receptor Activator Of Nuclear Factor- $\kappa B$ Ligand (RANKL). Further more, Epigallocatechin gallate (EGCG) and theaflavin (TF) detoxify molecules of ROS and enhance osteoblastogenesis. This study concluded that administration of Kombucha tea fermented on 14 days make osteoblasts in the mandibular bone of wistar rat more numerous.
\end{abstract}

Keywords : Kombucha Tea, Alveolar bone, Osteoblast

\section{PENDAHULUAN}

Manusia yang telah memasuki usia diatas 55 tahun mengalami proses penuaan secara alamiah yang nantinya akan menimbulkan masalah kesehatan, mental, sosial, ekonomi, dan psikologis. ${ }^{1}$ Osteoporosis merupakan salah satu masalah kesehatan yang dialami oleh para lanjut usia. ${ }^{1}$ Perkembangan ekonomi dan teknologi membuat kaum muda yang ambisius dalam mengejar karir terbuai dalam aktifitasnya sehingga lupa aktif bergerak setiap hari, minimal berjalan kaki dan memiliki pola hidup yang tidak sehat sehingga tidak memperhatikan asupan makanan yang masuk ke dalam tubuh, kebiasaan-kebiasaan tersebut membuat kaum muda tersebut rawan menderita osteoporosis dini. ${ }^{2}$

Osteoporosis adalah penyakit tulang dengan karakteristik massa tulang yang rendah, terjadi kerusakan mikro-arsitektur jaringan tulang yang mempengaruhi kekuatan tulang dan meningkatkan resiko keropos tulang. ${ }^{1}$ Osteoporosis ditandai dengan adanya massa tulang yang rendah yang memicu kerapuhan tulang dan meningkatkan kejadian fraktur tulang. ${ }^{3}$ Sel osteoblas dan sel osteoklas berperan dalam pengaturan metabolisme tulang dan keduanya terlibat dalam perkembangan osteoporosis. ${ }^{1}$ Ketidakseimbangan antara pembentukan tulang dan resorpsi tulang adalah kunci dari patofisiologi dari penyakit tulang pada orang dewasa termasuk osteoporosis. ${ }^{3}$

Kerangka manusia dewasa memiliki total 213 tulang yang memiliki berbagai fungsi, selain memberikan dukungan struktural untuk tubuh dan tempat melekatnya otot-otot, melindungi struktur organ vital dan membantu pemeliharaan homeostasis mineral dan keseimbangan asam-basa, berfungsi sebagai reservoir faktor pertumbuhan dan sitokin serta menyediakan lingkungan untuk hematopoesis dalam sumsum tulang. ${ }^{3}$ Setiap tulang selalu mengalami remodeling selama hidup untuk membantu beradaptasi dengan perubahan kekuatan biomekanik, serta perombakan tulang yang tua dan mengalami kerusakan mikro dan menggantinya dengan yang baru. ${ }^{4}$

Tulang memiliki beberapa fungsi penting sebagai tempat penyimpanan kalsium dan fosfor. Fungsi tersebut sangat penting untuk regulasi kalsium dan fosfor dalam darah yang dipengaruhi oleh asupan mineral dalam usus dan sekresi mineral dalam urin. ${ }^{5}$ Mekanisme homeostasis tulang diatur oleh hormon paratiroid (PTH), Calcitonin (CT) dan vitamin D. Proses pembentukan tulang yang memelihara kesehatan tulang dapat dikategorikan sebagai program pencegahan, secara kontinyu mengganti tulang yang lama dan menggantikannya dengan tulang yang baru. ${ }^{4}$ Kehilangan massa tulang terjadi saat keseimbangan proses pembentukan tulang terganggu sehingga resorpsi tulang lebih banyak dari pembentukan tulang baru. $^{3}$

Remodeling tulang adalah proses dimana tulang diperbarui untuk menjaga kekuatan tulang dan homeostasis mineral. ${ }^{5}$ Perombakan melibatkan penghapusan terus menerus tulang yang sudah tua, penggantian ini memiliki sintesis matriks protein yang baru, dan mineralisasi matriks selanjutnya untuk membentuk tulang baru. ${ }^{3}$ Proses remodeling tulang meresorpsi tulang yang lama dan membentuk tulang baru untuk mencegah akumulasi tulang dengan kerusakan mikro. ${ }^{4}$ 
Unit remodeling tulang terdiri dari sel osteoklas dan sel osteoblas yang secara berurutan melaksanakan resorpsi tulang tua dan pembentukan tulang baru. ${ }^{6}$ Siklus remodeling terdiri dari empat fase berurutan yaitu aktivasi, resorpsi, pembalikan dan pembentukan. ${ }^{5}$ Tempat perombakan dapat berkembang secara acak tetapi juga ditargetkan ke daerah-daerah yang memerlukan perbaikan tulang. ${ }^{6}$ Jaringan tulang tidaklah statik, tulang yang sehat memerlukan proses remodeling dan modeling secara kontinyu untuk mempertahankan fungsi penunjang dan sebagai regulator homeostasis mineral. ${ }^{5}$

Beberapa penelitian melaporkan adanya efek stress oksidatif terhadap diferensiasi dan fungsi sel osteoklas serta pengaruhnya terhadap peningkatan kehilangan massa tulang. ${ }^{7}$ Sebuah studi epidemiologi mengindikasi hubungan antara asupan antioksidan dan kesehatan tulang. ${ }^{8}$ Stress oksidatif dapat menghambat pertumbuhan tulang dengan cara menghambat diferensiasi sel osteoblas melalui extracellular signalregulated kinase (ERK) dan ERK-dependent nuclear factor- $k B$ signaling pathway. ${ }^{37}$

Reactive Oxygen Species (ROS) merupakan molekul yang sangat reaktif, mengandung molekul oksigen dan radikal bebas, termasuk hidroksil $(\mathrm{OH})$ dan radikal superoksida $\left(\mathrm{O}_{2}\right)$, hidrogen peroksida $\left(\mathrm{H}_{2} \mathrm{O}_{2}\right)$, oksigen singlet, dan peroksida lemak. ${ }^{9}$ ROS dapat mengakibatkan stres oksidatif karena sifat radikal bebasnya menyebabkan kerusakan beberapa biomolekul, seperti DNA, protein, dan lipid. ${ }^{9}$ ROS dihasilkan oleh mitokondria, selanjutnya produksi ROS akan mengaktivasi jalur regulasi proses inflamasi melalui mekanisme aktivasi $E R K$ dan ERK selanjutnya akan mengaktivasi produksi Nuclear Factor $k B$ (NF$\mathrm{kB})$ dan NF-kB akan merangsang produksi sitokin proinflamasi, seperti TNF- $\alpha$ dan IL-6. TNF- $\alpha$ dan IL-6 akan meningkatkan osteoklastogenesis, menghambat apoptosis sel osteoklas dan menghambat aktivasi sel osteoblas. $^{10}$

Kehilangan gigi sering dikaitkan dengan penyakit periodontal pada orang lanjut usia. ${ }^{11}$ Beberapa studi menunjukkan bahwa osteoporosis terkait dengan penurunan kepadatan tulang alveolar dan kehilangan tulang alveolar. ${ }^{11}$ Efek penuaan pada jaringan periodontal didasarkan pada perubahan molekul dalam sel periodontal, seperti terjadinya resorpsi tulang. ${ }^{11}$ Anatomi tulang alveolar bervariasi pada setiap pasien dan memiliki implikasi klinis yang penting. ${ }^{12}$ Tinggi dan ketebalan tulang pada bagian fasial dan lingual dipengaruhi kesejajaran gigi, angulasi akar terhadap tulang dan tekanan oklusal. ${ }^{12}$ Tulang alveolar merupakan jaringan periodontal yang paling stabil karena sturkturnya terus-menerus berubah secara konstan. ${ }^{12}$ Terjadi remodeling internal seperti resorpsi dan formasi serta diregulasi oleh faktor lokal dan faktor sistemik. $^{12}$ Faktor lokal yang dimaksud adalah perubahan sel tulang. ${ }^{12}$ Remodeling tulang alveolar mempengaruhi tinggi, kontur dan densitas tulang, manifestasinya terlihat dalam tiga area yaitu jarak periodontal ligament, hubungan periosteum pada fasial dan lingual serta permukaan endosteal pada ruang sumsum. ${ }^{11}$
Substansi interstisial tulang terdiri atas dua komponen utama yaitu matriks organik sebanyak 35\% dan garam-garam anorganik sejumlah $65 \%$. Matriks organik terdiri atas $90 \%$ serat-serat kolagen yang terbenam dalam substansi dasar kaya proteoglikan, terutama kolagen tipe I. $^{6}$ Bahan anorganik tulang terdiri atas endapan sejenis kalsium fosfat submikroskopik. ${ }^{4}$ Pada tulang yang aktif bertumbuh, terdapat empat jenis sel yaitu sel osteoprogenitor, sel osteoblas, osteosit dan sel osteoklas. $^{6}$ Sel osteoprogenitor paling aktif selama pertumbuhan tulang dan akan diaktifkan kembali semasa kehidupan dewasa saat pemulihan fraktur tulang dan bentuk cerea lainnya. ${ }^{4}$

Sel osteoblas adalah sel pembentuktulang yang berkembang dan berperan dalam pengaturan metabolisme tulang, termasuk tulang alveolar yang menyangga gigi. ${ }^{10}$ Selama deposisi aktif dari matriks baru, mereka tersusun sebagai lapis epiteloid sel-sel kuboid atau kolumnar pada permukaan tulang. Inti sel osteoblas biasanya terletak pada ujung sel paling jauh dari permukaan tulang. ${ }^{6}$ Sitoplasmanya sangat basofilik dan sebuah kompleks Golgi tampak mencolok sebagai daerah lebih pucat antara inti dan dasar sel. Pada mikrograph elektrik, sel osteoblas memiliki struktur yang diharapkan dari sel yang aktif menghasilkan protein. ${ }^{10}$ Retikulum endoplasmanya yang luas ditaburi ribosom dan banyak ribosom bebas terdapat dalam sitoplasma. ${ }^{4}$

Meskipun sel osteoblas terpolarisasi terhadap tulang dibawahnya, pembebasan produknya agaknya tidak terbatas pada kutub basal karena ada sel diantaranya yang berangsur-angsur diselubungi oleh sekretnya sendiri dan ditransformasi menjadi osteosit, terkurung dalam matriks tulang yang baru dibentuk. ${ }^{10}$ Selain mensekresi berbagai unsur matriks seperti kolagen tipe I, proteoglikan, osteokalsin, osteonektin, dan osteopoetin, sel osteoblas juga menghasilkan faktor penumbuh yang memiliki efek autokrin dan parakrin penting pada pertumbuhan tulang. ${ }^{6}$ Mereka juga memiliki reseptor permukaan terhadap berbagai hormon, vitamin, dan sitokin yang mempengaruhi aktivitasnya.$^{10}$

Osteoporosis sebenarnya dapat dicegah sejak dini dengan membudayakan perilaku hidup sehat yaitu mengkonsumsi makanan dengan gizi seimbang yang memenuhi kebutuhan nutrisi dengan unsur kaya serat, rendah lemak dan kaya kalsium (1000-1200 mg kalsium perhari), berolahraga secara teratur, tidak merokok dan tidak mengkonsumsi minuman beralkohol.Pengobatan osteoporosis dapat dilakukan dengan obat kalsium, vitamin D dan terapi hormon estrogen pengganti. ${ }^{13}$

Namun pemberian hormon estrogen memiliki efek samping seperti obesitas dan migren serta dapat meningkatkan risiko terjadinya hiperplasia bahkan kanker payudara dan endometrium. ${ }^{1}$ Efek samping tersebut dapat dikurangi dengan pemberian hormon kombinasi antara estrogen dan progesteron, namun hal ini masih diperdebatkan para ahli dan peneliti. ${ }^{13}$

Masyarakat cenderung memilih penggunaan bahan-bahan dari alam untuk pencegahan maupun 
pengobatan. $^{13}$ Pemerintah pun telah mengatur pemanfaatan herbal medik dalam fasilitas kesehatan melalui beberapa peraturan pemerintah, keputusan menteri, maupun peraturan perundang-undangan sejak 1998 hingga kini. ${ }^{14}$

Teh merupakan minuman herbal populer didunia, mengkonsumsi teh merupakan kebiasaan sebagian besar masyarakat. ${ }^{15}$ Manfaat teh dapat ditingkatkan apabila dilakukan proses fermentasi dengan bantuan mikroorganisme menghasilkan suatu produk minuman yang disebut Kombucha tea. Kelebihan Kombucha tea dibandingkan teh, selain citarasa Kombucha tea lebih segar, banyaknya senyawa aktif pada Kombucha tea yang tidak dijumpai pada teh, sementara senyawa aktif dalam tehnya sendiri tidak mengalami perubahan. ${ }^{14}$

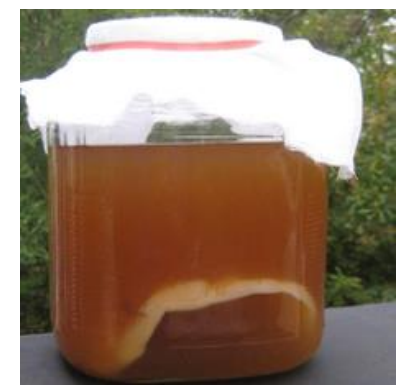

Gambar 1. Fermentasi Kombucha tea

Jamur Kombucha difermentasi dalam campuran yang mengandungair, teh hitamatau teh hijau, gula dancuka, mikroorganisme terkombinasi menjadi kultur fermentasi yang kompleks. ${ }^{14}$ Kultur ini menghasilkan beberapa senyawa yang telah dianggap sebagai tonik kesehatan selama berabad-abad. ${ }^{15}$ Kultur Kombucha teadapat mencakup beberapa jenis ragi dan bakteri seperti Saccharomycodes ludwigii, Schizosaccharomyces pombe, Brettanomyces bruxellensis, Bacterium xylinum, Bacterium gluconicum, Bacterium xylinoides, Bacterium katogenum, Pichia fermentans dan Candida stellata. ${ }^{15}$

Teh mengandung senyawa polifenol, alkaloid, asam amino, karbohidrat, protein, klorofil, mineral dan komponen lainnya. ${ }^{14}$ Diantara senyawa-senyawa tersebut, polifenol merupakan senyawa yang memiliki aktivitas antioksidan yang paling kuat. ${ }^{16}$ Aktivitas antioksidan Kombucha tea meningkat sejalan dengan lamanya fermentasi. ${ }^{17}$ Selama fermentasi, bakteri dan jamur mengubah sukrosa menjadi asam organik. ${ }^{17}$ Dalam fermentasi tersebut, kultur Kombucha akan menghasilkan sejumlah alkohol (0,5-1\%), karbon dioksida, vitamin B kompleks (B1/tiamin, B2/riboflavin, B3/niasin, B6/piridoksin, $\mathrm{B} 12 /$ sianokobalamin, vitamin $\mathrm{C}$, asam folat, asam glukoronat, asam asetat, asam laktat, asam amino esensial, enzim, antibiotik dan kandungan lain seperti polifenol. ${ }^{18}$ Didalamnya juga berisi pendetoks hati, antioksidan, polifenol, probiotik, dan bentuk bebasasam amino. Salah satu kandungannya, yaitu polifenol merupakan senyawa yang memiliki aktivitas antioksidan yang paling kuat. ${ }^{15}$
Polifenol yang terdapat dalam Kombucha tea yaitu epicatechin (EC), epigallocatechin (EGC), epicatechin gallate (ECG), epigallocatechin gallate (EGCG), theaflavin (TF) dan thearubigins (TR). ${ }^{19}$ Salah satu katekin yaitu EGC, dapat menstimulasi diferensiasi sel osteoblas dan menghambat induksi Receptor Activator Of Nuclear Factor- $\kappa B$ Ligand (RANKL) dalam diferensiasi osteoklas. ${ }^{20}$ EGCG dan theaflavin dapat meningkatkan jumlah sel osteoblas, osteoblastogenesis, dan pembentukan tulang, terbukti dengan adanya peningkatan kelangsungan hidup osteoblastik, proliferasi dan diferensiasi tulang. ${ }^{10}$ EGCG memiliki pengaruh imunomodulasi sehingga menghambat pengeluaran mediator proinflamasi, seperti TNF- $\alpha$, interleukin- $\beta$ (IL- $\beta$ ), $\gamma$-interferon, dan prostaglandin $\mathrm{E}_{2}\left(\mathrm{PGE}_{2}\right)$. Mediator-mediator tersebut dapat menghambat aktivasi sel osteoblas. ${ }^{10}$

Penelitian terhadap efek antimikroba dalam Kombucha tea sebagian besar karena adanya asam organik, asam asetat, protein dan katekin. ${ }^{21}$ Beberapa penelitian melaporkan bahwa Kombucha tea membantu sistem pencernaan sebagai laksatif, mencegah infeksi mikroba dan meningkatkan imunitas tubuh. ${ }^{22}$

Berdasarkan penelitian yang telah disebutkan di atas menunjukkan bahwa Kombucha tea mempunyai antioksidan yang mampu mempengaruhi pertumbuhan tulang, sehingga peneliti berkeinginan untuk meneliti apakah Kombucha tea mampu meningkatkan jumlah sel osteoblas tulang alveolarsecara in vivo.

\section{BAHAN DAN METODE}

Bahan yang digunakan dalam penelitian ini adalah starter Kombucha, teh hitam dan gula pasir untuk membuat Kombucha tea.

\section{Rancangan Penelitian}

Penelitian ini merupakan penelitian eksperimen sesungguhnya (true experimental) menggunakan rancangan The Randomized Posttest Control Group Design. Sampel adalah tikus jenis wistar jantan berusia 3 bulan dengan kisaran berat 150 hingga 200 gram yang dibagi menjadi dua kelompok, yaitu kelompok kontrol dan kelompok perlakuan, masing-masing kelompok terdiri dari 5 ekor. Kelompok kontrol adalah sampel yang mendapat pemberian aquadest steril selama 30 hari dan kelompok perlakuan adalah sampel yang mendapat pemberiam Kombucha tea sebanyak $8 \mathrm{ml}$ selama 30 hari.

\section{Pembuatan Kombucha tea}

$$
\text { Pembuatan Kombucha tea dengan }
$$
menggunakan starter Kombucha. Satu liter air dipanaskan hingga mendidih dalam wadah stainless steel, kemudian dituangkan 100 gram gula pasir dan dicelupkan 2 kantong teh hitam kedalamnya serta dibiarkan sekitar 15 menit hingga teh larut didalamnya. Teh disaring dengan kain saring ke dalam wadah yang terbuat dari kaca dan sudah disterilkan. Setelah teh dalam keadaan dingin atau dalam suhu ruangan, starter Kombucha dimasukkan kedalam teh tersebut dan ditutup dengan kain kasa steril yang diikat dengan karet. Fermentasi dibiarkan selama 14 hari dalam suhu 
ruangan. Setelah fermentasi selesai, teh dimasukkan ke dalam botol steril dan disimpan dalam lemari pendingin. Sisa teh dan starter Kombucha, dapat digunakan kembali dengan langkah seperti diatas.

\section{Protokol penelitian}

Kombucha tea hasil fermentasi 14 hari diberikan pada tikus kelompok perlakuan sebanyak 8 ml dengan cara sonde lambung saat kondisi tikus tenang.Pemberian Kombucha tea dilakukan setiap hari selama 30 hari.

Hari ke-31, tikus di-euthanasia dengan metode inhalasi menggunakan ether. Setelah tikus mati, tikus diletakkan terlentang pada tatakan dan keempat kakinya difiksasi dengan jarum. Kulit di bagian mandibuladibersihkan sampai terlihat tulang mandibular secara utuh.

Pemotongan tulang mandibula dilakukan dari temporomandibular joint kanan sampai bagian temporomandibular joint kiri. Tulang mandibula yang telah dipotong disimpan dalam botol formalin untuk dibuat sediaan mikroskopik. Sisa jaringan yang tidak digunakan dikubur.

Dekalsifikasi tulang mandibula dengan Sodium citrate dan Acid formic selama 4 hari. Tissue processing dengan perendaman di alkohol bertingkat selama \pm 21 jam. Blocking dengan cairan paraffin. Jaringan dalam paraffin dipotong dengan mikrotom. Kemudian potongan jaringan tersebut ditempelkan pada kaca obyek. Pewarnaan jaringan dengan pewarnaan Harris Hematoxylin - eosin (HE). Secara berurutan jaringan pada kaca obyek dimasukkan dalam:Xylol, Xylol, Xylol, Alkohol 100\%, Alkohol 100\%, Akuades, Hematoxilin, Akuades, Eosin, Alkohol 96\%, Alkohol 96\%, Alkohol 96\%, Alkohol $100 \%$, Alkohol 100\%, Xylol, Xylol. Mounting dengan entelan untuk merekatkan cover glass ke kaca obyek dan disimpan dalam inkubator selama \pm 24 jam. Pembacaan jumlah sel osteoblas dengan cara menghitung jumlah sel yang terlihat pada mikroskop dengan pembesaran 400x.

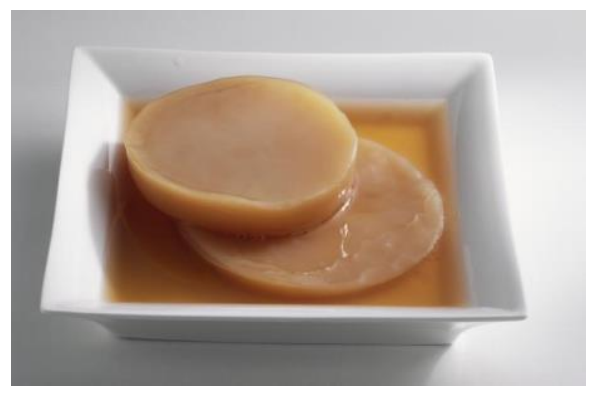

Gambar 2. Starter Kombucha

\section{HASIL DAN PEMBAHASAN}

Analisis data dilakukan sebagai dasar untuk mengetahui karakteristik data yang dimiliki. Analisis data dilakukan dengan program SPSS. Pemilihan penyajian data dan uji hipotesis tergantung dari normal tidaknya distribusi data. Distribusi data diuji normalitasnya dengan Uji Shapiro-Wilk dengan tingkat kemaknaan 5\%. Data berdistribusi normal dengan nilai $\mathrm{p}>0,05$. Data diuji homogenitasnya dengan uji homogenity of variance test dengan Levene's Test (Uji F) dengan tingkat kemaknaan 5\%. Data homogen dengan nilai $p>0,05$. Data berdistribusi normal dan bersifat homogen maka dilakukan analisis komparatif data antar kelompok dilakukan dengan uji independent T-test. Hasil analisis kemaknaan dengan independent T-test disajikan pada Tabel.

Tabel Rerata jumlah sel osteoblas antar kelompok

\begin{tabular}{lcccccc}
\hline & $\mathrm{n}$ & $\begin{array}{c}\text { Rerata } \\
\text { Jumlah } \\
\text { Osteoblas }\end{array}$ & SB & $\begin{array}{c}\text { Beda } \\
\text { Rerata }\end{array}$ & $\mathrm{t}$ & $\mathrm{p}$ \\
\hline Kontrol & 5 & 106,56 & 8,80 & & & \\
Perlakuan & 5 & 143,06 & 14,37 & 36,5 & 8,66 & 0,00 \\
\hline
\end{tabular}

Berdasarkan hasil penelitian di atas, didapatkan bahwa terjadi peningkatan jumlah sel osteoblas tulang mandibula tikus wistar jantan secara bermakna pada kelompok perlakuan yang diberikan Kombucha tea fermentasi 14 hari. Kelebihan Kombucha tea dibandingkan teh, selain citarasa Kombucha tea lebih segar, banyaknya senyawa aktif pada Kombucha tea yang tidak dijumpai pada teh, sementara senyawa aktif dalam tehnya sendiri tidak mengalami perubahan. ${ }^{14}$ Jamur Kombucha difermentasi dalam campuran yang mengandung air, teh hitam atau teh hijau, gula dan cuka, mikroorganisme terkombinasi menjadi kultur fermentasi yang kompleks. ${ }^{14}$ Kultur ini menghasilkan beberapa senyawa yang telah dianggap sebagai tonik kesehatan selama berabad-abad. ${ }^{15}$ Kultur Kombucha tea dapat mencakup beberapa jenis ragi dan bakteri seperti Saccharomycodes ludwigii, Schizosaccharomyces pombe, Brettanomyces bruxellensis, Bacterium xylinum, Bacterium gluconicum, Bacterium xylinoides, Bacterium katogenum, Pichia fermentans dan Candida stellata. ${ }^{15}$ Selama fermentasi, bakteri dan jamur mengubah sukrosa menjadi asam organik. ${ }^{17}$ Dalam fermentasi tersebut, kultur Kombucha akan menghasilkan sejumlah alkohol (0,5-1\%), karbon dioksida, vitamin B kompleks (B1/tiamin, B2/riboflavin, B3/niasin, B6/piridoksin, B12/sianokobalamin, vitamin C, asam folat, asam glukoronat, asam asetat, asam laktat, asam amino esensial, enzim, antibiotik dan kandungan lain seperti polifenol. ${ }^{18}$ Didalamnya juga berisi pendetoks hati, antioksidan, polifenol, probiotik, dan bentuk bebas asam amino. Salah satu kandungannya, yaitu polifenol merupakan senyawa yang memiliki aktivitas antioksidan yang paling kuat. ${ }^{15}$

Penelitian terhadap efek antimikroba dalam Kombucha tea sebagian besar karena adanya asam organik, asam asetat, protein dan katekin. ${ }^{21}$ Beberapa penelitian melaporkan bahwa Kombucha tea membantu sistem pencernaan sebagai laksatif, mencegah infeksi mikroba dan meningkatkan imunitas tubuh. ${ }^{22}$ Polifenol yang terdapat dalam Kombucha tea yaitu epicatechin (EC), epigallocatechin (EGC), epicatechin gallate (ECG), epigallocatechin gallate (EGCG), theaflavin (TF) dan thearubigins (TR). ${ }^{19}$ Salah satu katekin yaitu EGC, dapat menstimulasi diferensiasi sel osteoblas dan menghambat induksi Receptor Activator Of Nuclear 
Factor- $\kappa B$ Ligand (RANKL) dalam diferensiasi osteoklas. ${ }^{20}$ EGCG dan theaflavin dapat meningkatkan jumlah sel osteoblas, osteoblastogenesis, dan pembentukan tulang, terbukti dengan adanya peningkatan kelangsungan hidup osteoblastik, proliferasi dan diferensiasi tulang. ${ }^{10}$ EGCG memiliki pengaruh imunomodulasi sehingga menghambat pengeluaran mediator proinflamasi, seperti TNF- $\alpha$, interleukin- $\beta$ (IL- $\beta$ ), $\gamma$-interferon, dan prostaglandin $\mathrm{E}_{2}$ $\left(\mathrm{PGE}_{2}\right)$. Mediator-mediator tersebut dapat menghambat aktivasi sel osteoblas. ${ }^{10}$

EGCG yang memiliki aktivitas antioksidatif, mampu menangkap dan mendetoksifikasi Reactive Oxygen Species (ROS), yang merupakan radikal bebas dan dapat menyebabkan peningkatan aktivasi osteoklas, osteoklastogenesis dan menghambat aktivasi sel osteoblas. Detoksifikasi terhadap ROS dapat menghambat resorpsi tulang oleh sel osteoklas dan meningkatkan aktivasi sel osteoblas.

\section{SIMPULAN}

Berdasarkan hasil penelitian diatas, bahwa jumlah sel osteoblas tulang mandibula tikus wistar jantan lebih tinggi padapemberian Kombucha tea fermentasi 14 hari.Perlu dilakukan penelitian lebih lanjut terhadap bahan aktif Kombucha tea yang memiliki peran sebagai anti oksidan.

\section{DAFTAR PUSTAKA}

1. National Osteoporosis Foundation. Clinician's Guide to Prevention and Treatment of Osteoporosis. Washington, DC; 2014

2. Mulyaningsih, F.Mencegah dan Mengatasi Osteoporosis dengan Berolahraga, Fakultas Ilmu Keolahragaan, Univeritas Negeri Yogyakarta; 2008

3. Shen CL, Yeh JK, Cao J, Wang JS. 2010. Green Tea and Bone Metabolism, Nutrition Research 2010; 29 (7): 437-456.

4. Standring S. Musculoskeletal system. In: Gray's Anatomy. $39^{\text {th }}$ Ed. New York: Elsevier; 2004; h. 83-135.

5. Lerner. Bone Remodeling in Post-menopausal Osteoporosis. J Dent Res 2006; 85(7):584-595.

6. Clarke B. Normal Bone Anatomy and Physiology, ClinJ AmSocNephrol2008; 3(Suppl 3): S131-S139.

7. Bai XC, Lu D, Bai J, Zheng H, Ke ZY, Li XM, Luo SQ.Oxidative stress inhibits osteoblastic differentiation of bone cells by ERk and NF-kB. $J$ Biochemical and Biophysical Research Communications 2004;314: 197-207.

8. Rao LG, Kang N, Rao AV. Polyphenol antioxidants and bone health: A Review, Phytochemicals - A Global Perspective of Their Role in Nutrition and Health. Dr. Venketeshwer Rao. Intech: 2012. h. 467-486.
9. Baek KH, Oh KW, Lee, WY, Lee SS, Kim MK, Kwon HS, Rhee EJ, Ham JH, Song KH, Cha BY, Lee KW, Kang MI. Association of oxidative stress with postmenopausal osteoporosis and the effects of hydrogen peroxide on osteoclast formation in human bone marrow cell cultures. Calcif Tissues Int 2010; 87(3):226-235.

10. Vali B, Rao LG, El-Sohemi A. Epigallocatechin-3gallate increases the formation of mineralized bone nidules by human osteoblast-like cells. J Nut Bio 2007; 18:341-347.

11. Hebling E. Effects Of Human Ageing On Periodontal Tissues. Inperiodontal Diseases-A Clinician's Guide 2012. InTech Rijeka. 2012.

12. Carranza K, Takei N. Carranza's Clinical Periodontology. 12 $2^{\text {th }}$ ed. Elsevier Saunders. 2012; h. 40-44.

13. Wratsangka R. Terapi Sulih Hormon Untuk Meningkatkan Kesehatan Wanita Menopause. J Kedokter Trisakti, September-Desember 1999;18 (3) :155-162.

14. Rinihapsari E, Richter CA. Fermentasi Kombucha dan Potensinya Sebagai Minuman Kesehatan. STIFAR Yayasan Pharmasi Semarang. Media Farmasi Indonesia 2008; 3 (2) : 241-246.

15. Cavusoglu K, Guler P. Protective Effect Of Kombucha Mushroom (KM) Tea On Chromosomal Aberrations Induced By Gamma Radiation In Human Peripheral Lymphocytes In Vitro. J. Environ. Biol 2010; 31, 5: 851-856.

16. Cabrera C, Nez RG, and Loä PMC. Determination of Tea Components with Antioxidant Activity. $J$. Agric. Food Chem 2003; 51: 4427-4435.

17. Suhartatik N, Kurniawati L. Aktivitas Antioksidan Kombucha dari Teh Celup dan Teh Racik Selama Fermentasi. Eksplorasi XX (1) 2008; h. 116-123.

18. Naland H. Kombucha Teh Dengan Seribu Khasiat. Agromedia Pustaka. Jakarta: 2008; h. 2-58.

19. Jayabalan R, Marimuthu S, Swaminathan K. Changes in content of organic acids and tea polyphenols during kombucha tea fermentation. Food Chem 2007;102 : 392-398.

20. Ko CH, Lau KM, Wing YC, Leung PC. Effect of Tea Cathechins, Epigallaocathechin, Gallocatechin and Gallocatechin Gallate, on Bone Metabolism. J. Agri. Food Chem 2009; 57 : 7293-7297.

21. Jayabalan R, Malbasa RV, Loncar ES, Vitas JS, Sathishkumar M. A Review on Kombucha Tea Microbiology, Composition, Fermentation, Beneficial Effects, Toxicity, and Tea Fungus. Comprehensive Reviews in Food Science and Food Safety 2014;13 : 538 - 550.

22. Dufresne C, Farnworth E.Tea, Kombucha, and health: a review. Food Research International 2007; 33: 409-421. 